\title{
第87回日本動物学会沖縄大会シンポジウム「ホルモン研究の現状と新展開 〜新規ホルモン探索の課題とホルモン機能の多様性〜」開催記
}

\author{
矢澤 隆志 (旭川医大・生化学) \\ E-mail: yazawa@asahikawa-med.ac.jp
}

\section{開催概要}

ホルモン研究の現状と新展開〜新規ホルモン探索の課題 とホルモン機能の多様性〜

会場 : 沖縄コンベンションセンター B棟 $2 \mathrm{~F}$ ( $\mathrm{Bd}$ 会場)

日程：2016年11月 17日 (17:15〜 19:15)

オーガナイザー：海谷啓之 (国循) ・矢澤隆志 (旭川医大) 演者・演題 :

・井田隆徳 (宮崎大) : 新規ペプチド探索について〜ホ ルモン探索の現状と未来

・永田さやか (宮崎大) : 組織アンジオテンシン II 生成 における新規ペプチドの単離

・岩田恵理 (いわき明星大)：脳内ペプチドによる硬骨 魚類の行動調節

・佐藤貴弘 (久留米大)：生体リズムとホルモン〜自律 神経系への作用について

・根本崇宏 (日本医大) : ストレスと栄養がホルモン分 泌に与える影響

一見華やかに見える本学会のテーマであるホルモン研 究も、哺乳類においては 10 年以上も新規ペプチドが見 つかっておらず、ポストゲノム時代の今、新たな局面を 迎えていると言っても過言ではない。そのような中、ペ プチド・ホルモン研究会は、2011年3月に宮崎で産声 を上げた、ホルモン研究の新展開を模索する中堅・若手 研究者が集う会である。日本比較内分泌学会との関連で は、2012年11月の福井大会で、サテライト企画として、 比較内分泌学会の若手の会と共催されたことを記憶され ている方もいらっしゃると思う。研究会は、その後も毎 年必ず開催されており、今年9月に久留米で7回目の開 催を迎えている。福井で開催した当時は、立ち上げ直後 ということもあり、体制を整えつつ開催しているような

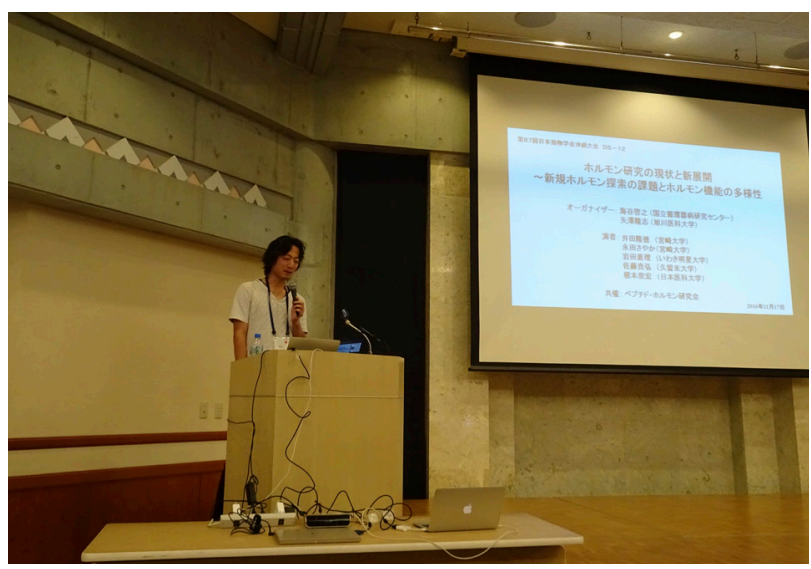

写真1 オープニングトーク (筆者)
状況にあった研究会も、そこから4回の開催を重ね、成 熟期に入ってきたとも言える。そんな研究会で育まれた ホルモン研究に対する熱いメッセージを学会で発信しよ うと、研究会メンバーの中で最年長の海谷氏と 2 番目の 私がオーガナイズする形で、井田・永田・岩田・佐藤・ 根本の 5 人のメンバーが、第 87 回日本動物学会沖縄大 会に「ホルモン研究の現状と新展開〜新規ホルモン探索 の課題とホルモン機能の多様性〜」と題したシンポジウ ムで打って出ることになった。余談になるが、オーガナ イザーの 2 人は、 20 年来の動物学会員であるが、演者の 5人は、計画時点で非会員または幽霊会員という状況が、 打って出るという言葉を如実に表していたと思う。

講演は、前半 2 題が新規ペプチドの探索、後半3題は 既知ホルモンの新機能の解析に分かれ、5人の演者が最 後のスライドで今後のホルモン研究の展望を提言すると いう形式で行われた (写真 1)。トップバッターの井田は、 新規ペプチド探索の現状と未来に関して講演した。さま ざまな動物種から新規ペプチドを発見し続ける見事な研 究内容に加えて、いつもながらの笑いありの講演は、最 後にラボの過剩なまでの宣伝と学生のリクルートで締め くくるも、そこだけは不発? 永田は、アンジオテンシン II 産生過程における新たなペプチドの探索と発見に関す る内容で講演を行い、応用できてこそホルモン研究とい う提言は、病院の内科の現場で研究を行っている研究者 らしさを感じさせた。岩田は、カクレクマノミの社会行 動と脳内ペプチドの関連という、沖縄開催のシンポジウ ムに相応しいテーマで講演し、neuroethology分野にお けるぺプチドの新たな機能解明と発展が期待される内容 であった。佐藤は、グレリンが体内リズムを司るという $\mathrm{KO}$ マウスの詳細な解析から発見した新機能に関する講 演を行った。その提言は、哲学的で壮大な内容であった

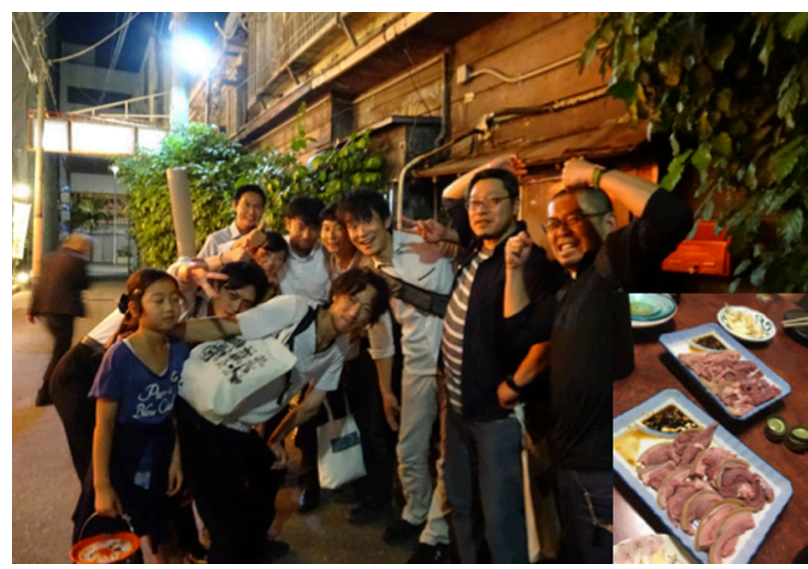

写真2 シンポジスト達との慰労会 (右下 : ヤギ肉) 
が、突き止めるところまで突き止める」というグレリン 機能を詳細に解析してきた研究スタイルそのものだった。 シンポジウムの最後を飾った根本は、ストレスとホルモ ンという内容で講演を行い、DOHaD (Developmental Origin of Health and Disease : 胎児期、さらには胎児に なる前の胎芽期や乳児期の環境因子が、成長後の健康や 様々な疾病の発症リスクに影響を及ぼすという概念）に よる乳幼児期の発達のコントロールが、既に医療の中で 応用に向かっていることを示した。以上のように、5人 の演者は、それぞれのオリジナリティーに富んだ研究を 動物学会という場でアピールすると同時に、各人のホル モン研究に対する熱い思いが聴衆の皆さんに伝わる内容 であり、当初の目標は十二分に達成できたと思う。

シンポジウム終了後は、皆で那覇市内に繰り出し、オ
リオンビールや泡盛を片手にヤギ料理を楽しみ、シンポ ジウムが無事に終了したことやその手応えに酔いしれる ひとときとなった (写真2)。そのような中で確認された のは、これに満足することなく、研究会において、まだ 先の見えないホルモン研究について一層議論を深め、さ らなるメッセージを発信していくことである。そして、 気は早いが、次のシンポジウムを見据えて精進していく ことを誓い、日付が変わつた国際通りを帰路に着いた。 来年は、長浜バイオ大学の奈良篤樹氏主催で研究会を行 うことが予定されている。興味がある方は、上記のシン ポジウムメンバーに御連絡いただければと思います。そ れでは、また、長浜或いはどこかの研究会でお会いしま しょう。

\section{第22回国際動物学会議・第87回日本動物学会沖縄大会合同大会に参加して}

高木 互 (理化学研究所・倉谷形態進化研究室) E-mail: wataru.takagi@riken.jp

2016年11月14日から 19日まで開催された第22回国 際動物学会議・第87回日本動物学会沖縄大会合同大会 に参加しました。大会を通して沖縄は好天に恵まれ、昼 間は $28^{\circ} \mathrm{C}$ 前後の汗ばむような気候でしたので、県外か ら参加された方は大きな気温差に驚かれたのではないで しょうか。本大会の会場は前半16日までが沖縄科学技 術大学院大学 (OIST: 恩納村) 、後半 17、18日が沖縄コ ンベンションセンター(OCC: 宜野湾市)、最終日の 19 日は沖縄夕イムスビル (那覇市) に分かれており、恩納 村に宿泊していた私は17日の OCCへ会場が移る朝は自 ら交通手段を確保しなければならず、不便さを感じるこ ともありました。ただ、広大な敷地と、洗練された意匠 の建物、充実した研究設備を有する OISTでの国際学会 は日本にいることを忘れてしまいそうな環境でした。ま た、OCCからは参加者も増え、ポスターセッションで は広い会場に多くの参加者が集まり、白熱した議論が交 わされた素晴らしい大会だったと思います(写真)。何 より、私にとっては2015年3月学位取得後に理研へ移 つて以来、初めての大きな学会への参加でしたので、久 しぶりにお会いした方々と連日連夜お話させていただけ たことが大変嬉しかったです。

本大会は日本で初めて開催された国際動物学会議との 合同大会ということで、これまでに参加した動物学会 （2010年東京、2012年大阪）と比べて、印象に残る違い がいくつかありました。まず一つ目は plenary lectureが 多く組まれており、海外の著名な研究者の生の講義を聞 く機会に恵まれたことです。海外からの参加者のほとん どが私の宿泊したホテルに滞在しており、私の現在行っ ているEvo-Devo 研究の大家であるオックスフォード大 学の Peter Holland 博士らとホテルのバーでお話できた ことも貴重な経験になりました。そして、二つ目は、本

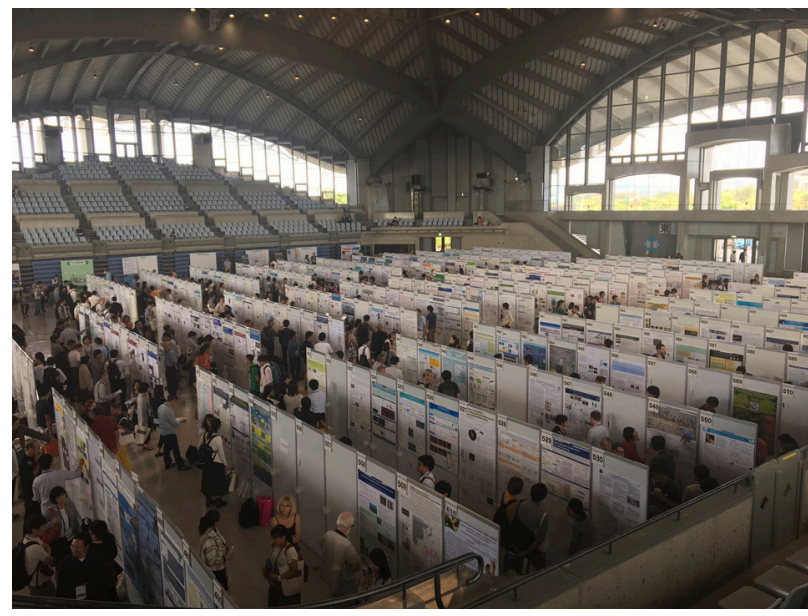

写真 OCCのポスター会場

大会の発表形式がシンポジウムの招待演者以外は全員ポ スター発表に限定されていたことです。口頭発表のみの 場合、研究分野あるいは動物種ごとに会場が分けられて いるため、複数の発表を同時に聞くことはできませんが、 今回は自分の興味の赴くままに多くのポスターを見て回 ることができたので、個人的にはとても満足しています。

私自身は「Evolutionary origin of vertebrate thyroid gland (脊椎動物甲状腺の進化的起源の解明)」という演題でポ スター発表を行い、同じ円口類でもヤツメウナギとヌタ ウナギで異なる甲状腺の発生パターンを示すことを紹介 しました。春椎動物の進化に関する研究では、公開ゲノ ム情報や胚を扱った研究が可能なヤツメウナギが顎口類 の外群としてょく用いられていますが、同じ円口類のヌ タウナギとでは生理学的・生態学的に異なる点も多いこ とから、顎口類の失った脊椎動物の共有祖先形質を円口 類に見出すためには、ヌタウナギ研究が必要であること 